See Article page 333.

\section{Commentary: Neighbors should keep their distance after esophagectomy}

\author{
Ruben G. Nava, MD, ${ }^{\mathrm{a}}$ Sean J. English, MD, ${ }^{\mathrm{b}}$ and \\ Daniel Kreisel, MD, $\mathrm{PhD}^{\mathrm{a}, \mathrm{c}}$
}

The presence of an aorto-conduit fistula after esophagectomy is a rare but life-threatening condition. In most cases, it is fatal without surgical intervention and poses a challenge for the entire medical team. The actual incidence is unknown, as there are few cases reported in the literature. Patients usually present with a "herald bleed," followed by a latent period and eventual exsanguination. Survival of this complication is generally dismal due to delays in diagnosis. ${ }^{1}$

Feczko and colleagues ${ }^{2}$ describe a patient who presented with massive hematemesis at 9 months after undergoing McKeown esophagectomy and provide a step-by-step description of the management of this patient. Although esophagogastroduodenoscopy seems to be a reasonable first step, massive hemorrhage could make it virtually impossible to obtain adequate visualization. Because time is of the essence, bypassing this step should be considered in selected cases. Making a diagnosis is critical to establishing an effective plan. It can be argued that if an aorto-conduit fistula is high in the differential, then direct transfer to a hybrid operating room will provide the surgical team with more flexibility to control the bleeding. Endovascular stent placement is an excellent treatment option to temporize the situation; however, this strategy it is not always technically feasible. Placement of an occlusive aortic balloon to control

From the ${ }^{\mathrm{a}}$ Division of Cardiothoracic Surgery, Department of Surgery, ${ }^{\mathrm{b}}$ Section of Vascular Surgery, Department of Surgery, and ${ }^{c}$ Department of Pathology and Immunology, Washington University School of Medicine, St Louis, Mo.

Disclosures: Dr Kreisel has a pending patent, "Compositions and methods for detecting CCR2 receptors" (application 15/611,577). All other authors reported no conflicts of interest.

The Journal policy requires editors and reviewers to disclose conflicts of interest and to decline handling or reviewing manuscripts for which they may have a conflict of interest. The editors and reviewers of this article have no conflicts of interest.

Received for publication Feb 16, 2021; revisions received Feb 16, 2021; accepted for publication Feb 22, 2021; available ahead of print Feb 27, 2021.

Address for reprints: Daniel Kreisel, MD, PhD, Department of Surgery, Washington University School of Medicine, Campus Box 8109, 660 South Euclid Ave, St. Louis, MO, 63110 (E-mail: kreiseld@wustl.edu).

JTCVS Techniques 2021;7:338-9

2666-2507

Copyright (c) 2021 The Authors. Published by Elsevier Inc. on behalf of The American Association for Thoracic Surgery. This is an open access article under the CC BY-NCND license (http://creativecommons.org/licenses/by-nc-nd/4.0/).

https://doi.org/10.1016/j.xjtc.2021.02.030
Check for updates

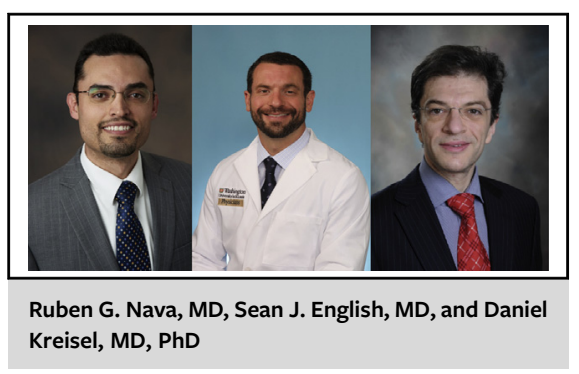

CENTRAL MESSAGE

Prompt recognition and multi-

disciplinary communication are

critical to the successful man-

agement of an almost always

lethal complication of

esophagectomy.

the bleeding is a good alternative, as illustrated by this case. The use of a left thoracoabdominal approach allowed the authors to gain control of the aorta with supraceliac clamping and repositioning of the occlusive aortic balloon below the fistula. In the end, this resulted in a successful primary repair.

The use of endovascular stent placement has been previously reported in this setting. Although it can provide much needed time for patient resuscitation and stabilization, this treatment modality has a high likelihood of failure due to chronic infection and/or erosion of the stent into the conduit. ${ }^{3}$ The operative principles of managing infected endovascular stents include graft excision and wide debridement of infected tissues. Surgical options include extra-anatomic bypass and reconstruction with arterial or venous allografts or autologous grafts, such as the neoaortoiliac system (NAIS procedure), which may be more resistant to infection. ${ }^{4}$ Antibiotic-soaked prosthetic grafts, possibly in combination with antibiotic-loaded polymethylmethacrylate (PMMA) beads, also may be considered as alternatives in such infected fields. ${ }^{5,6}$ Bovine pericardium represents another excellent option for in situ reconstruction; however, despite its high biocompatibility, it does not provide absolute protection when perivascular infection is ongoing. ${ }^{7,8}$ Consideration for palliation may have a role in patients with poor cancer prognosis.

We commend the authors for their extraordinary efforts in the management of their patient. We agree that early diagnosis, rapid control of bleeding, and definitive repair are paramount for the successful management of these 
patients, as conservative management generally fails. A high degree of collaboration from a multidisciplinary standpoint and substantial resource mobilization are essential to achieve a successful outcome. Overall, the strategy presented by Feczko and colleagues should be a welcome guide to any surgeon facing this complex situation.

\section{References}

1. Molina-Navarro C, Hosking SW, Hayward SJ, Flowerdew AD. Gastroaortic fistula as an early complication of esophagectomy. Ann Thorac Surg. 2001;72:1783-8.

2. Feczko AF, Sudarshan M, Smolock CJ, Raja S. Successful management of aorto-conduit fistula after esophagectomy: Tips and tricks to avoid catastrophe. J Thorac Cardiovasc Surg Tech. 2021;7:333-5.

3. Chotai HS, Finch G, Thomas D, Libertiny G. Successful management of an aorto-gastric fistula occurring 15 years after oesophagectomy with covered aortic stent graft placement followed by open surgery. J Surg Case Rep. 2018; 2018:rjy019.

4. Kilic A, Arnaoutakis DJ, Reifsnyder T, Black JH III, Abularrage CJ Perler BA, et al. Management of infected vascular grafts. Vasc Med. 2016;21:53-60

5. Charlton-Ouw KM, Kubrusly F, Sandhu HK, Swick MC, Leake SS, Gulbis BE, et al. In vitro efficacy of antibiotic beads in treating abdominal vascular graft infections. J Vasc Surg. 2015;62:1048-53.

6. Escobar GA, Eliason JL, Hurie J, Arya S, Rectenwald JE, Coleman DM Rifampin soaking Dacron-based endografts for implantation in infected aortic aneurysms-new application of a time-tested principle. Ann Vasc Surg. 2014 28:744-8.

7. Belkorissat RA, Sadoul C, Bouziane Z, Saba C, Salomon C, Malikov S, et al Tubular reconstruction with bovine pericardium xenografts to treat native aortic infections. Ann Vasc Surg. 2020;64:27-32.

8. Lutz B, Reeps C, Biro G, Knappich C, Zimmermann A, Eckstein HH. Bovine pericardium as new technical option for in situ reconstruction of aortic graft infection. Ann Vasc Surg. 2017;41:118-26. 